\title{
The heterogeneity of urban soils in the light of their properties
}

\author{
Andrzej Greinert
}

Received: 14 January 2014 / Accepted: 10 December 2014 / Published online: 9 January 2015

(C) The Author(s) 2015. This article is published with open access at Springerlink.com

\begin{abstract}
Purpose Despite 30 years of work on the issue of urban soils, there are still differences in opinions on the real significance of soil diversity for the functionality of urban areas. This also reflects a significant difference in the perception of the environment itself by representatives of natural sciences and engineering.

Materials and methods The research was carried out in the town and administrative commune of Zielona Góra-a medium-sized town located in the western part of Poland $\left(51^{\circ} 56^{\prime} 07^{\prime \prime} \mathrm{N}, 15^{\circ} 30^{\prime} 13^{\prime \prime} \mathrm{E}\right)$. This paper is a synthesis of more than a decade of research on soils covering the Zielona Góra urban area. A total of 562 samples were analysed from 105 soil profiles (to a depth of $150 \mathrm{~cm}$ ) and 32 additional surface samples. Soils were classified according to the WRB 2007. Laboratory tests were conducted using standard procedures for soil investigation.

Results and discussion As a result of the research, several soil groups were identified in a relatively small area-Podzols, Brunic Arenosols, Luvisols, Albeluvisols, Gleysols, Phaeozems as well as large areas covered by Hortic Anthrosols, Technic Regosols, Technic Arenosols, Mollic Technosols, Urbic Technosols and Ekranic Technosols. It was found that the transformation of soil under different land use forms was diversified, which was especially connected with soil profile decapitation, building rubble admixture, admixture of wastes, soil covering and compacting. As a consequence of this, different soil properties were noted, especially
\end{abstract}

Responsible editor: Jean Louis Morel

A. Greinert $(\triangle)$

Department of Land Protection and Reclamation, Faculty of Civil

and Environmental Engineering, University of Zielona Góra, ul.

Prof. Z. Szafrana 15, 65-516 Zielona Góra, Poland

e-mail: A.Greinert@iis.uz.zgora.pl calcium carbonate content, $\mathrm{pH}, \mathrm{EC}$ and concentrations of $\mathrm{Cu}$, $\mathrm{Pb}$ and $\mathrm{Zn}$.

Conclusions Urban soils are frequently characterized by a strong horizontal and vertical heterogeneity. The differentiation of the soil sites is significantly related to the site age, human impact intensity and the form of land use. Not all properties of soils within urban areas are spatially strongly diversified when areas with a similar construction and use are taken into account. $\mathrm{pH}$ values and particle size distribution are unified over large areas of the city.

Keywords Soil diversity $\cdot$ Technosols $\cdot$ Urban soils

\section{Introduction}

The total urban area of the world increases every year. According to contemporary statistics, 100 of the biggest cities occupy about $182,000 \mathrm{~km}^{2}$, and 200 of them occupy about $240,000 \mathrm{~km}^{2}$ (City Mayors 2013). About $6 \%$ of the total area of Europe is urban, and it still increases by $0.34-0.5 \%$ every 5 years between 2000-2015 (UN 2011). Rapid urbanization has resulted in uncontrolled peri-urbanization, and following this is the transformation of soil. Many problems connected with cities and their environmental indices concern the increasing number of people. Nowadays, about $52 \%$ of the world's population live in cities, in Europe about 73 \% (EEA 2010; UN 2012). This index is increasing exponentially. The urban areas of the world are expected to absorb all of the population growth expected over the next four decades (Vassigh and vom Hove 2012). Forecasts indicate that by $2030,60 \%$ of the world's population will have the possibility of settling down in cities, and by 2050, $70 \%$, whereas in regions characterised by greater development this figure will reach $86 \%$ (UN 2012). 
In such a situation, two typical reactions to urban area recognition and description can be noted-simplification or complication: simplification because the larger and more complicated an area is, the more difficult it is to comprehend; complication because the number of local factors influencing the soils increases, which is worthy of individual description from a scientific point of view.

In contemporary ecology, urban areas are composed of different ecosystems. Their composition is very complicated, especially now, when large new areas are included into cities. The consequences of this are the features of urban areas described by Cadenasso and Pickett (2008). The nature of urban surfaces is complex because of soil genesis and different influences on the soil (Greinert 2003; Pickett and Cadenasso 2009). Depending on the level of chemical inputs, soils can be slightly transformed (without consequences for soil classification) so far as to become toxic (indicated by a toxic qualifier in the name of soil) or highly reactive.

Special attention should be paid to the uniqueness of the spatial and vertical distribution of soil parent-rocks and a high share of technogenic materials within. Their properties and degree of differentiation, and in many cases their ease of decomposition, strongly influence the state of urban soils (Siem et al. 1987; Morel et al. 2005; Pickett and Cadenasso 2009; Huot et al. 2013). The presence of technogenic materials also strongly influences the potential direction of the migration of water and elements dissolved in the soil profile. This factor is partly responsible for the dissemination of pollutants towards the soil-water-plant system (El Khalil et al. 2008). Arbeitskreis Stadtböden der DBG (Urban Soils Working Group of the German Soil Science Society) pointed out the types of technogenic materials acting as parent rocks for urban soils (Burghardt 1995, 1996): construction debris, slag, dust, rock material, lignite, coal, municipal waste and sludge.

The technical point of view (i.e. urban planning) is often different - soil is described as a part of the urban surface used by the majority of vegetation as a root zone $(0-20 \mathrm{~cm})$. It means that there is no soil below $20 \mathrm{~cm}$. In such a situation, the similarity of urban soils is obvious, which results from the same technologies used for the development of the surface (Shane 2005). The same view on this problem presents itself in geology and geotechnical sciences, describing topsoil which directly covers rock materials (Berhane and Welraevens 2013). This approach to urban soils is associated with the simplification of their role in a described environment - only as an area under development. The consequences of this situation are a high level of similarity of soil materials, easy and frequent transformations of soils and a lack of interest in recognizing the deeper levels lying below the soil.

Topsoil is frequently removed from an area prior to construction. Subsoil may also be placed as a fill over topsoil.
Changing the order of the soil horizons or mixing the topsoil and subsoil are commonly observed phenomena in the city.

According to Berhane and Welraevens (2013), the role of geology and engineering geology in urban planning began to be recognized in practice a long time ago. It is very clear that such a thesis is obvious for technical sciences. The problem for today is to include as many considerations as are necessary into soil science.

This paper is a synthesis of more than a decade of research on soils covering the Zielona Gora urban area. The main objective of this study is to demonstrate the scale and degree of differentiation of soils in a selected urban area. On the basis of field studies, including soil site description and laboratory tests, basic indices were estimated - differentiating and unifying the description of urban soil cover.

\section{Methods and area description}

\subsection{Location}

The soil study was carried out in the area of the town and administrative commune of Zielona Góra (Fig. 1). Zielona Góra is a medium-sized town inhabited by about 110,000 residents and located in the western part of Poland (51 $51^{\circ}$ $\mathrm{N}, 15^{\circ} 30^{\prime} \mathrm{E}$ ). The town's history dates back to the beginning of the fourteenth century. Research sites were selected in areas illustrating particular stages of human impact on the natural environment and different land use.

\subsection{Geological description}

From the geological and geomorphological perspective, Zielona Góra is located in the Middle-Odra-Land, on two geomorphological landforms: the Zielona Góra Moraine Belt (max. height $221 \mathrm{~m}$ a.s.1.) and the Chynów-Płoty Basin (about $80 \mathrm{~m}$ a.s.l.). The Moraine belt has a latitudinal shape and is situated between two main ice marginal valleys: WarsawBerlin and Głogow-Baruth (Podgajna 2010). Most of the geological materials building the soil profile of the Zielona Góra locality are medium and coarse sands of glacial and alluvial origin, gravels and, in some areas, silts and clays within glaciotectonically disturbed moraine structures (Wróbel 1989; Gontaszewska and Krainski 2007). The role of sands is particularly large in the municipality of Zielona Góra-significantly higher than within the rest of the region. The Elder Quaternary era, the Pleistocene, is represented in Zielona Góra by brown marl moraine clay, fluvioglacial sand and gravel deposits, which build the kame terrace north of the Zielona Góra Moraine Embankment and the sandur terrace south of the said formation. The end moraine is constructed from powerfully disturbed beds of sands, gravels, boulders and clays. The younger age of the Quaternary, the Holocene, 

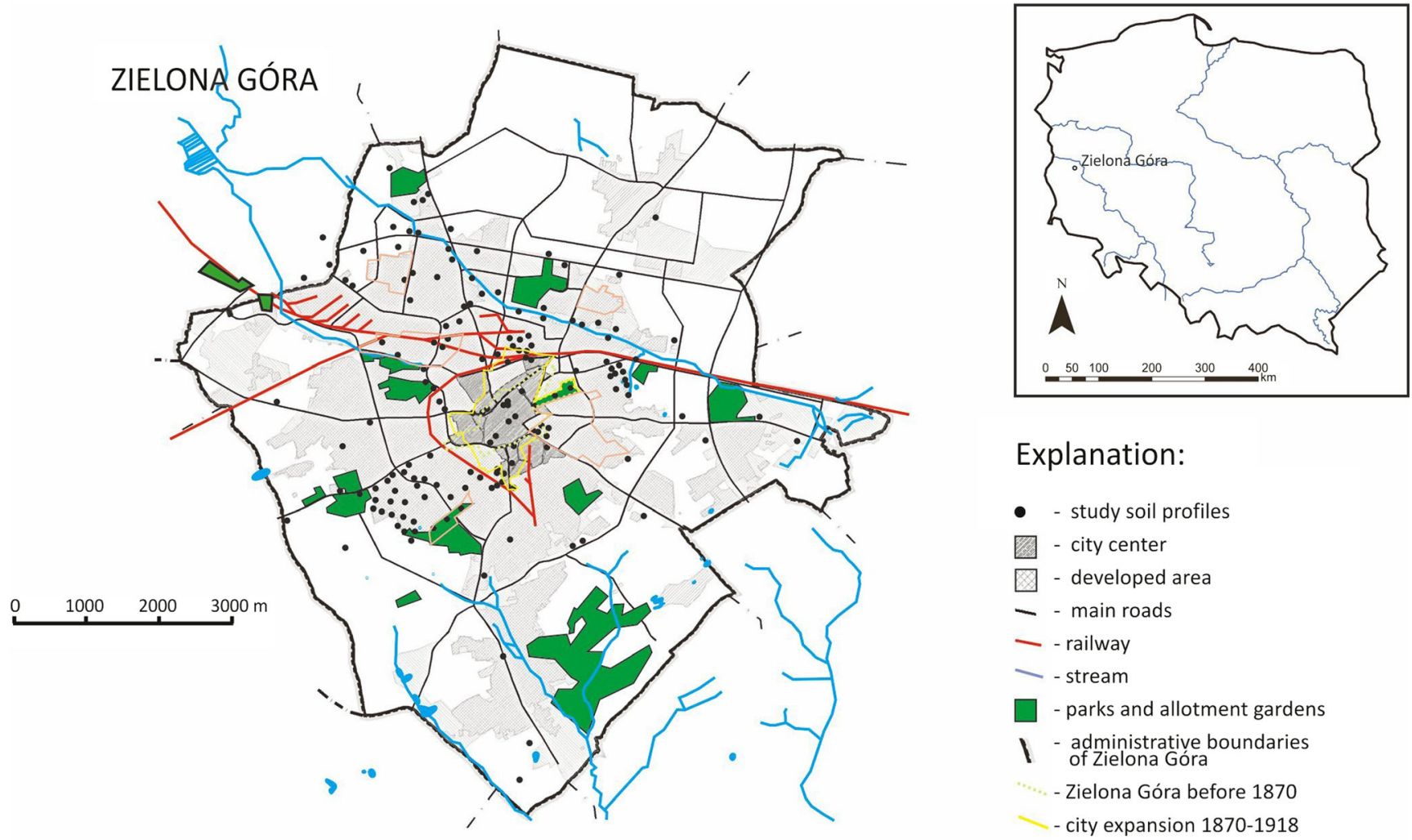

Explanation:

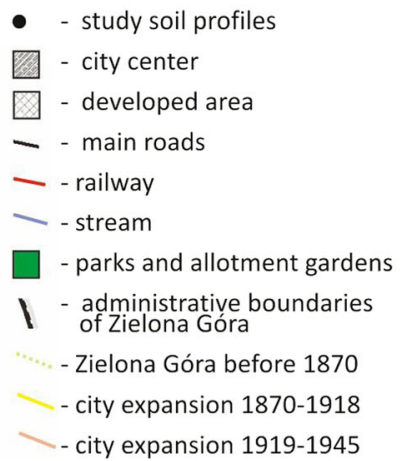

Fig. 1 Location of the soil sites under investigation with data about the development of Zielona Góra over time

is reflected by the richness of soil parent materials found in the upper layers of the whole area: peat, chalk, gyttjas, sands and lakeside loams, organic muds, sands and gravels.

Besides natural materials, the described area is rich in artificial deposits connected with human activities, mainly related to house and road building. Locally, there are also deposits of industrial and municipal wastes, especially in the areas of former open pits, excavations and subsidences. A phenomenon typical of the city is the prevalence of slag as an admixture in the soil profiles. This is due to the widespread use of this material through most of the twentieth century as a terrain filling material for the road surface or the substructure.

The climate conditions are typical of the transition area, influenced by the oceanic and continental climate. During a period of 30 years, the following average values were recorded: annual mean temperature $9.0^{\circ} \mathrm{C}$, $\min .-22^{\circ} \mathrm{C}(\mathrm{I})$, max. + $35.3{ }^{\circ} \mathrm{C}$ (VII); annual precipitation $572 \mathrm{~mm}$ (high annual volatility $505-757 \mathrm{~mm}$ from 2000 to 2011); number of rainy days per year 175.1; winds from the western sector above $50 \%$ of the wind rose; wind velocity $3.2 \mathrm{~m} \mathrm{~s}^{-1}$, $\max .34 \mathrm{~m} \mathrm{~s}^{-1}$; number of cloudy days per year 109; atmospheric pressure $993.2 \mathrm{hPa}$, min. $978.9 \mathrm{hPa}$, max. $1006.1 \mathrm{hPa}$; snow cover 50.7 days (Dancewicz 2010).

\subsection{Natural soil cover}

In the close surroundings of Zielona Góra, the presence of Podzols is a typical phenomenon. This is a clear result of pine monocultures as the dominant form of production forests, which has been observed since the nineteenth century. Forests have replaced most of the arable lands, and according to current data, they cover $45.1 \%$ of the town and $57.0 \%$ of the municipality. The processes occurring under the pine forest have led to the formation of Brunic Arenosols (Greinert et al. 2013). In smaller areas, Luvisols, Albeluvisols, Gleysols and Phaeozems are found, according to WRB classification (IUSS Working Group WRB 2007).

\subsection{Soil sampling and analytical methods}

In total, 105 soil profiles were tested- 530 samples were taken from each of the technical layers or genetic horizons. In the following areas, the given numbers of soil profiles were made: roadsides 20 , squares 19 , barren land 15 , sealed areas 15 , parks 15 , areas near the building 12, industrial areas 2 and forests 7. Next, 32 objects of approximately $20 \mathrm{~m}^{2}$ were chosen. From each object, one bulk surface sample was taken. In summary, 562 individual soil samples from soil horizons and the topsoil layer were taken for analyses in the years 
1999-2003 (Greinert 2003). In addition, about 100 other soil profiles were morphologically recognised by 2012 .

Soil samples were taken for analysis from the whole area of the city of Zielona Góra-roadsides, squares, sealed areas, parks, areas near buildings, industrial areas and areas surrounding the city (forests, barren land) (Fig. 1). Parks, squares, forests and barren land were chosen to reflect the different environmental impacts of human activities. The soil profiles were made in the most characteristic parts of each area. Pits were dug to a depth of $150 \mathrm{~cm}$. Soils were classified according to the classification by the IUSS Working Group WRB (2007). The surface soil samples were taken from more dispersed locations to show the diversity of local superficial impact. The bulk surface samples were only collected from the humus horizon, $0-(10-20) \mathrm{cm}$ in depth. Each of the bulk samples was mixed from 30 individual samples taken with a sampling stick.

The soil samples were collected in cardboard boxes, transported to the certified Central Laboratory of the Institute of Environmental Engineering in Zielona Góra (no. $\mathrm{AB} 772)$, air-dried $\left(35^{\circ} \mathrm{C}\right)$ and then passed through a $2-\mathrm{mm}$ sieve.

Particle size distribution was determined for both the $>2$ $\mathrm{mm}$ and sand fractions by sieving, and for silt and clay particles using the hydrometer method. The $\mathrm{pH}-\mathrm{H}_{2} \mathrm{O}$ and $\mathrm{pH}-0.01 \mathrm{M} \mathrm{CaCl}_{2}$ values were measured with a glass electrode WTW SenTix 41 in the 1:2.5 soil/supernatant suspension. Electrical conductivity (EC) of the soil-water extract was determined using the conductometric method. For the determination of the content of carbonates in the soil samples, the ISO 10693 method was used, based on the displacement of carbon dioxide by hydrochloric acid addition.

Extracts of soil samples were prepared in aqua regia (a mixture of concentrated acids $\mathrm{HCl} / \mathrm{HNO}_{3}$ in the proportion of $3: 1$ ) according to ISO 11466 , extracts in $0.1 \mathrm{M} \mathrm{HCl}$ according to Baker and Amacher (1982). This fraction is potentially available to plants. Additionally, water extracts using soil and water ratio of 1:10 were made, where the mixing time was $2 \mathrm{~h}$ of mixer rotations at $100 \mathrm{RPM}$ and a temperature of $23{ }^{\circ} \mathrm{C}$. The content of heavy metals in the soil samples was determined by atomic absorption FAAS (Varian SpectrAA $10)$.
All statistical analyses were conducted using Statistica for Windows 10 software. In the paper, selected basic statistical figures and correlations are shown.

\section{Results and discussion}

\subsection{Soil profile diversity}

The estimation of human impact on the soils of a fast spreading city is affected by a high degree of uncertainty. This is due to the overlapping of temporal variation in the scale and intensity of human impact on the soil and the spatial variety of a rapidly expanding city. New urban areas are usually former agricultural land and forests. The expansion of the urban area is, however, also an encroachment into areas previously used for municipal purposes, but not for residential or service ones, such as industrial sites or landfills. The presence of these sites outside the city reflects the impact taking place even before the direct urbanization of the area. Thus, the city occupies land already transformed in a way different from cultivation (Greinert 2013). This is also reflected in the wide ranges of soil properties indicated for a variety of typical urban constructions erected over different periods of the city's development (Table 1).

Urban soils are frequently characterized by a strong horizontal as well as vertical heterogeneity. However, not all of the characteristics and properties of urban soils are spatially strongly diversified when an area with uniform urban construction project is taken into account (Table 1). Both historical and contemporary urban areas could contain large amounts of skeleton parts in the soil-mainly of building rubble. The areas of Zielona Góra urbanised at the end of the twentieth century and at the beginning of the twenty-first century show a wider range of the skeleton content in the soil. First of all, it can be connected with the diversification of building technology, especially saving materials and waste management on the construction site. It can also be correlated with a particular location in the geological background of the city - a clear difference between the Zielona Góra Moraine Belt and the Chynów-Płoty Basin.

Table 1 The impact of urbanisation on the chemical properties of soils on the background of following periods of area construction

\begin{tabular}{lllccc}
\hline Typical form of area construction & $\begin{array}{l}\text { Skeleton (parts }>2 \mathrm{~mm}) \\
\%\end{array}$ & Parts $<0.02 \mathrm{~mm}$ & Parts $<0.002 \mathrm{~mm}$ & $\mathrm{TC}$ & $\mathrm{pH} 0.01 \mathrm{M} \mathrm{CaCl}{ }_{2}$ \\
\hline Nineteenth/twentieth century & $11.8-51.1$ & $1-25$ & $0-6$ & $0.39-3.26$ & $3.9-7.5$ \\
$50-60$ of twentieth century & $6.9-39.5$ & $1-11$ & $0-8$ & $0.32-1.68$ & $3.8-7.0$ \\
Contemporary & $0.4-79.9$ & $0-19$ & $0-9$ & $0.07-4.59$ & $3.8-7.5$ \\
Extensive & $0.0-58.7$ & $0-31$ & $0-15$ & $0.46-4.95$ & $3.2-5.1$ \\
\hline
\end{tabular}


Urban structures existing in Zielona Góra create large and compact spaces, easy for spatial separation. Despite a long history, most of the city is an area of fairly modern urbanisation, often very intensive (Fig. 1). This is a very important factor because primary urbanisation is characterized by a particularly intense impact on the soil.

On a local scale, the diversity of soils can be different than in the case of larger areas or a whole city. In this case, the land use form and the technology used for the construction of buildings and land development are very important. Park et al. (2010) noted that soil chemical properties vary with urban age. This variation could be analysed in transects in areas under similar development and contemporary human impact.

Different periods in the city's development, with different techniques, technologies and law regulations, affected differences in chemical compounds and elemental deposition. This action has a common schema: soil decapitation (deprivation of humic and organic horizons), deep mixing, admixture of rubble and other wastes, land levelling and covering with a horticultural bed. In the Zielona Góra area, land preparation for construction activities leads to the complete deterioration of the former soil. Thus, in such areas, initial soil with a simple construction of the soil profile $\mathrm{A}-\mathrm{C}$ is formed. In land subsidences, more complex soils are formed, with a layered cover under the former soil. The transformation of soil is clearly dependent on the form of land use. The analysis of the sites in Zielona Góra leads to conclusions about differences in soil transformations, especially between the areas of parks, forests, barren land (60, 57 and $40 \%$ of undisturbed soils) and other forms of use (0-5\% of undisturbed soils; Fig. $2 \mathrm{j}$, bars). In many cases, it is possible to observe a large amount of municipal wastes in the soil, especially in roadside areas, squares, areas near buildings and barren land. Their presence in the soil under the green square constructions and in the barren land is even higher than the presence of building rubble. The presence of wastes in the soil of parks and forests should also be worrying: in parks, $27-33 \%$ of soils with municipal wastes and $20 \%$ with building rubble; in forests, $29-43 \%$ and $14 \%$, respectively (Fig. 2b-d, bars). The location of a soil profile near a road and structural objects is connected with the mixing of soil horizons (Fig. 2i, bars) and compactness (Fig. 2h, bars). A typical occurrence for roadsides, and to a lesser extent also for squares, parks, areas near buildings and barren land, is the covering of soil with mineral material - usually construction sand (Fig. 2f, bars). As regards roadside areas, it can be observed that there is a model of building technology consisting of soil decapitation, next sand application, finally sealing the surface-Ekranic Technosols creation (Fig. 2e, bars).

The observations from Zielona Góra confirm the previous research by Kahle and Coburger (1996) carried out in Rostock (Germany). In Poland, the protection of organic and humic parts of soil during construction activities is regulated by law (Building Act). In practice, this is realised by pushing the topsoil onto the prism, which results in soil decapitation (Fig. 2a, bars). At the end of the construction process, new topsoil is formed partly from the old material and partly from the new one (Figs. 2g, bars, and 3). Generally, as a consequence of such a procedure, the unification of topsoil is noted all around the city. One of the most frequently discussed problems in urban ecology is the covering of huge areas with an impermeable surface of asphalt or concrete plates, called soil sealing. The total surface of roads, pavements and buildings means that Ekranic Technosols are of relatively high importance in urban areas.

In most of the anthropogenic transformed soils, the presence of waste materials was noted. These were miscellaneous materials with various properties and impact potential. The presence of technogenic materials is a factor that differentiates urban soils the most. The studies in the area of the city of Zielona Góra revealed the presence of wastes in soils, i.e. construction wastes in $61.1 \%$ of samples and brick parts in $20.4 \%$ of samples. However, an admixture of wastes in soil as a consequence of building activities is a typical, widespread situation. Wastes change the morphology and properties of soils, dominating the soil-forming processes and the soil evolution route. While studying the soil cover of the city of Essen, Meuser (1996) noted technogenic materials, mostly rubble, in $70 \%$ of sites. Blume and Runge (1978) noted $56 \%$ brick parts in Rendzina from rubble in Berlin. Nehls et al. (2013) reported that fine soil fractions of the urban soils of Berlin contained 3 to $5 \%$ of bricks, while the coarse fractions contained up to $50 \%$.

Anthropogenic transformation of most soils in the city is evidenced by the artificial profile construction with the domination of an abrupt and clear boundary of horizons; $82.4 \%$ of the analysed soil sites show these characteristics, mainly as a consequence of mechanical formation (Fig. 4).

A large number of the soil horizons show excessive compaction. While the topsoil horizons are mild as a consequence of mechanical cultivation and organic matter addition, the subsoil horizons are mostly dense or compacted. In the total number of the analysed horizons, this was recorded in $42.5 \%$ of cases. This is mainly a result of the use of heavy machinery during land levelling. A loose consistence was noted in $50.3 \%$ of horizons as a result of sandy textures. A similar problem was described by Weber et al. (1984), Short et al. (1986) and Jim (1998).

\subsection{Physico-chemical property diversity}

The transformation of the soil profile was reflected in many physical and chemical properties of the soils. The presence of building rubble containing calcium carbonate raised the content of carbonates in the soil. The described soil 

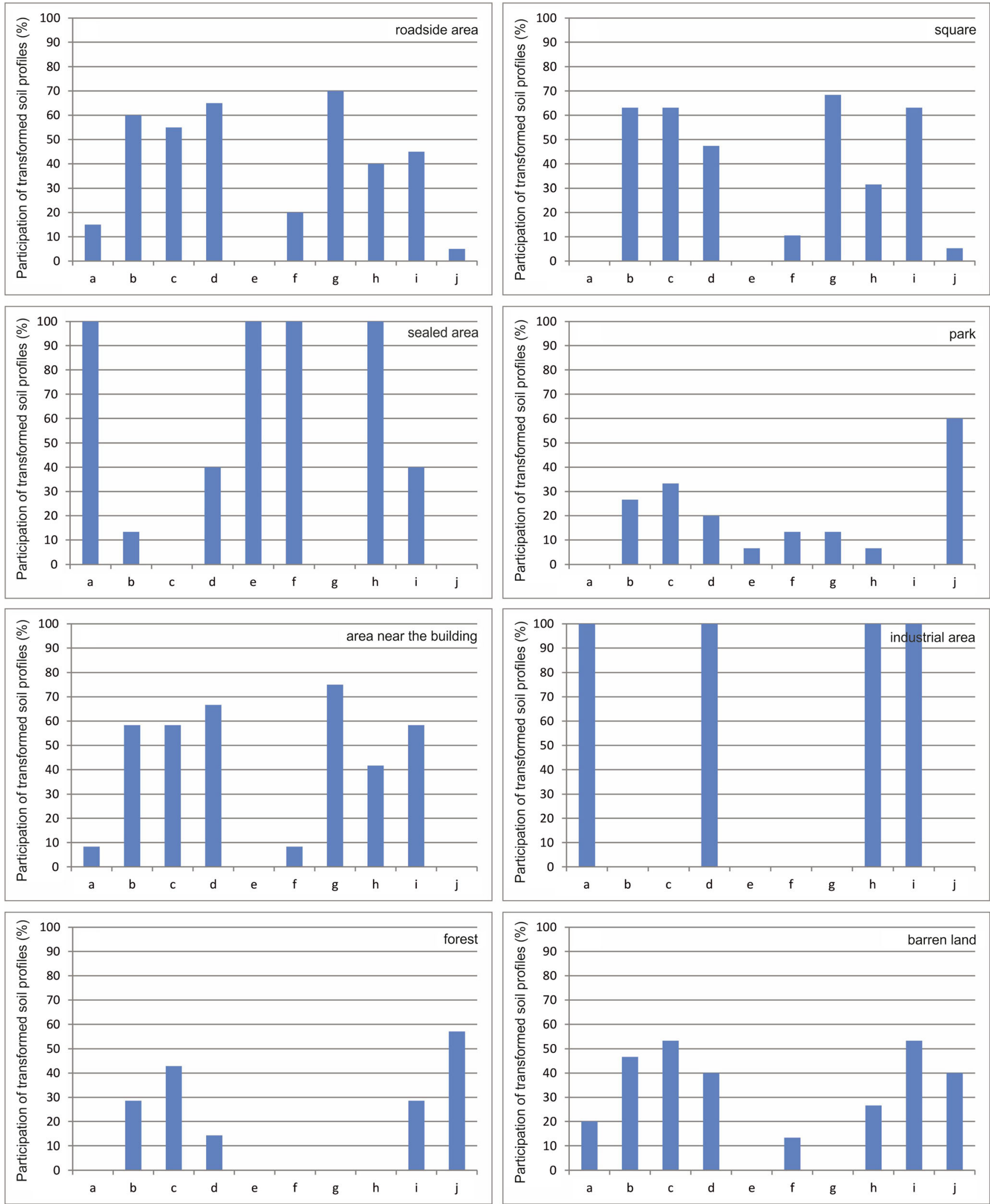

Fig. 2 Transformation of the soil profile in the area of the city of Zielona Góra: a decapitation of soil profile, $\mathbf{b}$ presence of municipal wastes, $\mathbf{c}$ superficial deposition of wastes, $\mathbf{d}$ presence of building rubble, e soil

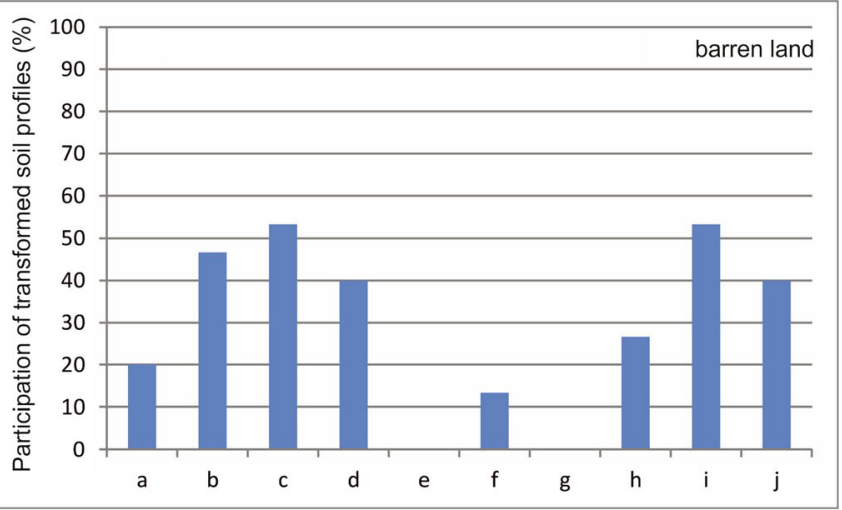

sealing, $\mathbf{f}$ covering of soil with mineral material, $\mathbf{g}$ covering of soil with organic material, $\mathbf{h}$ compactness, $\mathbf{i}$ mixing of soil horizons and $\mathbf{j}$ lack of transformations (unchanged soil profile) 


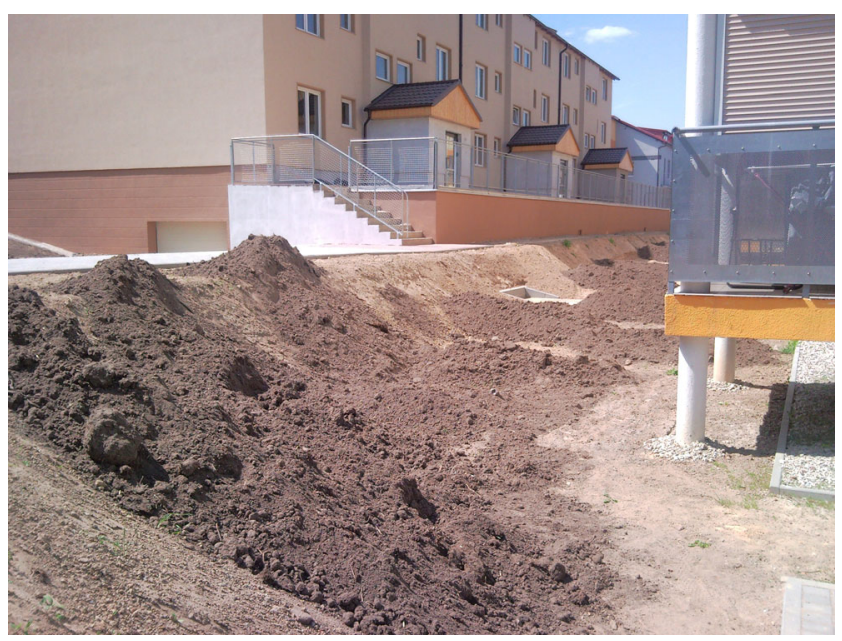

Fig. 3 Humic layer formation on a post-investment area (Zielona Góra; 2009)

transformations illustrate a potentially bigger chemical impact of construction processes in industrial areas, areas near buildings, roadsides and, to a smaller extent, squares and barren land. The analysis of the content of carbonates in the soil has proved this assumption - the average content of $6.86 \%$ in the soil of industrial areas and $6.28 \%$ in the soil of roadside areas (Fig. 5). In the urban area, various sources of carbonate should be taken into account, especially direct deposition (mixed into the soil matrix) and atmospheric deposition. For this reason, carbonates may be present in both the topsoil as well as the deeper horizons of the soil. A large surface deposition of carbonates was especially noted in industrial areas, areas near buildings and roadsides, higher than in deeper parts of the soil profile by 121,112 and $148 \%$ in these areas, respectively. Urban parks and squares are characterised by lower carbonate content than the other areas, especially in topsoil (ave. $3.41 \%$ of $\mathrm{CaCO}_{3}$ in park soil and 3.03 in squares). This is a result of human reclamation activities, which consist in putting an organic bed over a post-investment surface. Most of the substrates are prepared for coniferous plants; hence, they are not highly pre-limed. Barren land has almost the same carbonate content in the soil as forest and park areas (ave. $3.73 \%$ ). In the case of sealed areas, topsoil is not a typical part of the soil. It is rather a technical layer of sand and gravel to achieve an adequate stability of the technical surface of a concrete building, pavement, road or square. The average carbonate content was found to be about $37 \%$ lower in the topsoil than the deeper horizons ( 2.08 vs. $5.71 \%$ ). The levelling treatment, carried out during the construction of a concrete surface influencing several properties of Ekranic Technosols, was described by Charzynski et al. (2013).

The chemical content of roadsides reflects both the influence of the road as well as the unnecessary deposition of construction materials, but the surface deposition is relatively high (ave. 6.28 and $4.25 \%$ ) in comparison with the other municipal green areas.

One of the most frequently noted differences between anthropogenic soils and those of natural genesis/origin is the soil reaction. It is a property of high ecological importance. Studying the sites of Zielona Góra, an important difference in $\mathrm{pH}$ was noted in the case of topsoil and subsoil. The topsoil materials were neutral only in $21.9 \%$ of cases and alkaline in $9.4 \%$. In the case of the subsoil values, these were 24.4 and $50.7 \%$, respectively. There is a clearly visible difference in the post-investment soil treatment - the preparation of topsoil for greenery. The $\mathrm{pH}$ of the soils of the forest parks and forests was similar to that noted near the urban area:

Albic Luvisol- $\mathrm{pH}$ in $0.01 \mathrm{M} \mathrm{CaCl}_{2} 3.66-4.36$
Fig. 4 Horizon boundaries in the profiles from the area of Zielona Góra

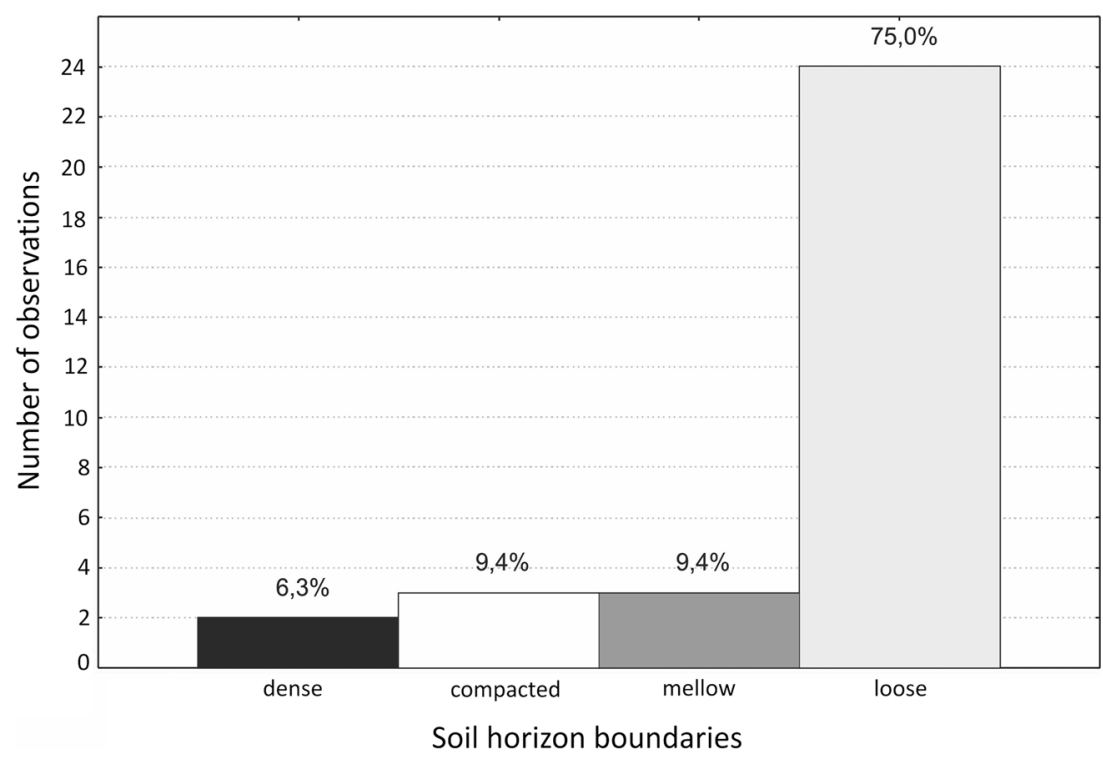


Fig. 5 Calcium carbonate content in soil against the background of the land use form

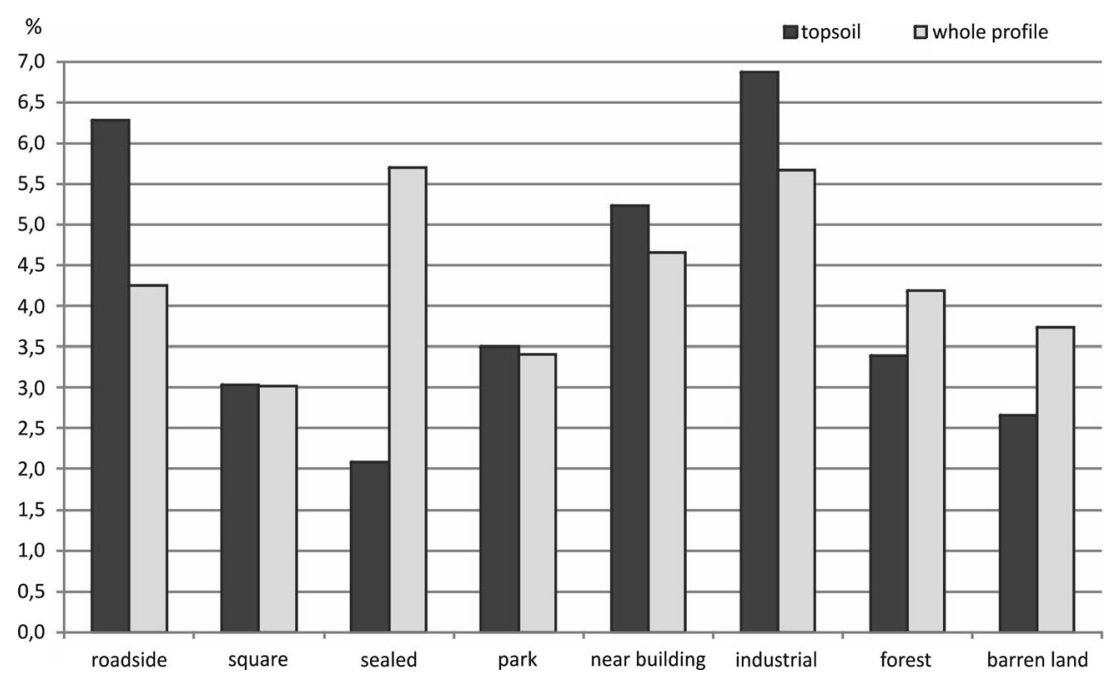

Albic Podzol (forest) - $\mathrm{pH}$ in $0.01 \mathrm{M} \mathrm{CaCl}_{2} 2.58-4.29$ Haplic Podzol (arable land) $-\mathrm{pH}$ in $0.01 \mathrm{M} \mathrm{CaCl}_{2} 3.12$ 4.32

Brunic Arenosol- $\mathrm{pH}$ in $0.01 \mathrm{M} \mathrm{CaCl}_{2} 4.02-4.99$

In the area of Zielona Góra, the $\mathrm{pH}$ of soils was very different. Occasionally, low $\mathrm{pH}$ values were noted in forests, forest parks and old municipal parks, but the median for those areas was $6.4 \pm 0.9$ for parks and $6.4 \pm 1.3$ for forests (Table 2).

For barren land, almost the same situation was noted. The median value for constructed Technosols was only $0.8 \mathrm{pH}$ higher than for the soils of parks and forests. The areas under high building impact (industrial areas, roadsides and sealed areas) show smaller differences between the minimum and maximum $\mathrm{pH}$ values. Older locations in the city are not very different from more modern ones (Table 1). Only extensively developed parts of Zielona Góra are covered with acid soils, which clearly illustrates less impact from building activities. Additionally, new topsoil material built with peat also shows an acid reaction.

A situation similar to the one described above is commonly known. In areas covered with Technosols, the acid reaction of soils is very rarely noted. It is a consequence of the widespread deposition of construction waste based on lime into the soil (Morel et al. 2005).
In some areas in the city, high salinity level is a problem. Soils of natural genesis in the Zielona Góra locality are typically characterised by a low EC $0.0-0.15 \mathrm{mS} \mathrm{cm}^{-1}$, which can be expected in the case of the occurrence of sandy materials. The situation is different within the city area-EC values ranging from 0.03 and $0.39 \mathrm{mS} \mathrm{cm} \mathrm{cm}^{-1}$ are most frequently observed in the topsoil, while in the case of the subsoil, they are between 0.00 and $2.50 \mathrm{mS} \mathrm{cm}^{-1}$. Electric conductivity is related to the soil texture and area location. Statistically, the EC value depended significantly on the content of forms of $\mathrm{Ca}$ $(r=0.74, \alpha=0.01), \mathrm{Na}(r=0.46, \alpha=0.01)$ and $\mathrm{K}(r=0.31, \alpha=$ $0.01)$ dissolved in water. The content of salts dissolved in water in soil depends on the form of land use, the presence of wastes and construction artefacts in the soil and the particular locality of the investigated site. The data collected in Table 3 show incidentally high results for all of the land use forms.

Median values are higher in the roadsides, which can be easily connected with the use of $\mathrm{NaCl}$ in winter. In areas near buildings, barren land and forests, this is connected with the deposition of waste materials (Fig. 2). Apart from these reasons in parks, this can be caused by the use of fertilizers. The level of electric conductivity of the soils presented by the median value is low in all of the described cases.

Table $2 \mathrm{pH}$ of soil depending on the land use form

\begin{tabular}{lllllllll}
\hline & Roadside & Square & Sealed area & Park & Area near the building & Industrial area & Forest & Barren land \\
\hline Minimum & 5.6 & 5.3 & 5.7 & 3.5 & 3.9 & 6.8 & 3.4 & 4.4 \\
Maximum & 7.7 & 8.3 & 7.9 & 7.5 & 8.2 & 7.3 & 7.1 & 7.5 \\
Median & 7.1 & 7.1 & 7.2 & 6.4 & 7.2 & 0.2 & 6.4 & 6.9 \\
Standard deviation & 0.4 & 0.6 & 0.4 & 0.9 & 1.0 & 1.3 & 0.7 \\
\hline
\end{tabular}


Table 3 Electric conductivity of soil depending on the land use form ( $\left.\mathrm{dS} \mathrm{m}^{-1}\right)$

\begin{tabular}{lcccccccc}
\hline & Roadside & Square & Sealed area & Park & Area near the building & Industrial area & Forest & Barren land \\
\hline Minimum & bdl & bdl & 0.03 & bdl & bdl & 0.04 & bdl & bdl \\
Maximum & 0.60 & 1.83 & 0.76 & 1.79 & 0.48 & 0.15 & 0.48 & 2.50 \\
Arithmetic mean & 0.22 & 0.18 & 0.15 & 0.23 & 0.20 & 0.07 & 0.21 & 0.37 \\
Standard deviation & 0.14 & 0.21 & 0.10 & 0.25 & 0.14 & 0.04 & 0.11 & 0.39 \\
\hline
\end{tabular}

$b d l$ below the detection limit

These results are confirmed by the investigations formerly made by Hiller and Meuser (1998) and Chernousenko et al. (2000). According to Hiller and Meuser (1998); most of the materials present in urban soils are characterised by the EC index, which is lower than $1.0 \mathrm{mS} \mathrm{cm}$. They associate high EC values with the presence of gypsum. They noted EC for industrial dust as $0.7-4.0 \mathrm{mS} \mathrm{cm}$, dust from coal heating plants $0.9-6.0 \mathrm{mS} \mathrm{cm}^{-1}$ and dust from lignite heating plants $2.4-3.1 \mathrm{mS} \mathrm{cm}^{-1}$. High values of the EC index were noted in ash from the burning of municipal wastes-10.5-20.2 $\mathrm{mS} \mathrm{cm}$. High EC values are also noted in the soil of industrial areas connected with food industry-a meat processing plant was active in Zielona Góra until the end of the twentieth century. Hulisz and Piernik (2013) described an even higher EC of soils affected by the soda plant in the city of Inowrocław, reaching 52 to $99 \mathrm{mS} \mathrm{cm}{ }^{-1}$. Similar results were noted by the author of this paper in the surroundings of Głogów after an emergency flow of saline groundwater from the pipeline transporting it from the mine (Greinert and Greinert 2007).

\subsection{Diversity of the heavy metal content}

For the Zielona Góra area, an important factor which differentiates the chemical composition of soils is the content of copper, lead and zinc (Table 4). Relatively high $\mathrm{Pb}$ and $\mathrm{Zn}$ values were recorded not only in roadside and sealed areas but also in parks and barren land.

An interesting situation can be observed with regard to the spatial distribution of $\mathrm{Cu}$. The highest values $(>400 \mathrm{mg}$ $\mathrm{Cu} \mathrm{kg}^{-1}$ ) were found in the areas of former vineyards (today's parks), where copper compounds had been used for fungal disease control. The Bordeaux mixture (a mixture of copper(II) sulphate $\left(\mathrm{CuSO}_{4}\right)$ and slaked lime $\left(\mathrm{Ca}(\mathrm{OH})_{2}\right)$ had been used in vineyards as a fungicide to control infestations of downy mildew, powdery mildew and other fungi since 1882 . The way in which $\mathrm{Zn}$ and $\mathrm{Pb}$ spread in the city of Zielona Góra is more complicated. This is due to both the history of the city as well as its reconstruction at the end of the twentieth century. During that time, many sites changed their earlier development. Information on different ways in which heavy metals are deposited in soil can be found in subject literature, i.e. directly with technogenic materials (Morel et al. 2005; El Khalil et al. 2008), indirectly with the superficial deposition of dusts and as a consequence of the aging of the components of utilities (Palm and Östlund 1996). The network of utilities is omnipresent in the city but with different densities and different kinds of materials. It can be assumed that this is a factor differentiating the soil both geo-mechanically (laying the network) and chemically (aging).

Very interesting results were noted in the case of heavy metal solubility. The entire spectrum was represented - from non-soluble to fully soluble forms of $\mathrm{Cu}$, $\mathrm{Pb}$ and $\mathrm{Zn}$ (Fig. 6).

A relatively high solubility of $\mathrm{Cu}$ was found in soils of industrial, roadside, sealed, park and barren land areas. The highest result shows an average share of the form dissolved in $0.1 \mathrm{M} \mathrm{HCl}$ in a subtotal content of $56.6 \%$ (industrial area). It was noted in an area not contaminated with copper, in soil with a very limited ability to sorb cations. The other areas were similar from this point of view. Above $40 \%$ of a potentially mobile form of $\mathrm{Pb}$ in the subtotal content was noted in sealed areas, industrial areas and forests. Also, those areas were not highly polluted with $\mathrm{Pb}$ in comparison with the other ones. The potential solubility of $\mathrm{Zn}$ was lower than that of the other two heavy metals. Relatively high indices, above $20 \%$, were noted for roadsides, sealed areas and parks.

\subsection{Examples of spatial soil diversity}

One very important aspect is the spatial distribution of urban soils - the location of a number of extremely different properties within a distance of several dozen meters has been noted.

The first of the areas selected to present this phenomenon is located in the city centre, about $200 \mathrm{~m}$ from the Old City Hall, just outside the medieval city walls. Until the 1990s, it had been a wasteland. Today, it has been developed as a commercial area. The distance between points $\mathrm{A}$ and $\mathrm{E}$ is about $50 \mathrm{~m}$. The differences in the construction of soil profiles are very clear (Fig. 7). According to the WRB soil classification system, different Urbic Technosols (A-D) and Urbic Technosol over Gleyic Podzol (E) can be recognised. 
Table 4 The heavy metal content in soil depending on the land use form ( $\left.\mathrm{mg} \mathrm{kg}^{-1}\right)$

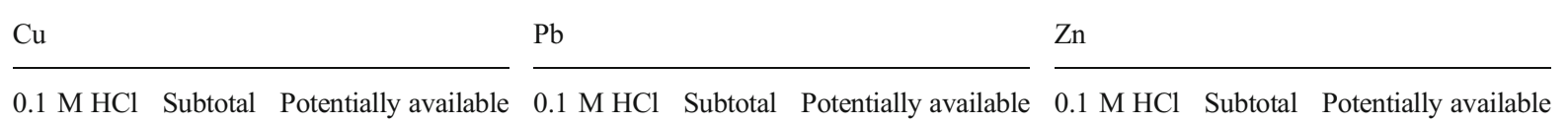

Roadside area

Max $\quad 323$

$\begin{array}{rr}5.5 & 1.1 \\ 294.5 & 98.4\end{array}$

0.4

4.2

1.0

$\begin{array}{lll}64.1 & 375.8 & 98.9\end{array}$

Mean $\quad 7.5$

$25.0 \quad 41.8$

11.7

$31.0 \quad 53.3$

Std. dev. $\quad 5.6$

$33.6 \quad 22.8$

10.1

$41.1 \quad 31.2$

Square

$\begin{array}{llll}\text { Min. } & 1.1 & 43 & 0.8\end{array}$

Max. 67.4

$\begin{array}{ll}4.3 \quad 0.8 \\ 145.7 & 81.6\end{array}$

0.6

51.3

$\begin{array}{ll}4.5 & 0.8\end{array}$

Mean $\quad 7.0$

$22.7 \quad 38.2$

Std. dev. $\quad 8.6$

$26.5 \quad 20.0$

11.2

602.8

97.4

$33.4 \quad 54.6$

$\begin{array}{lll}9.7 & 65.0 & 27.1\end{array}$

0.2

58.8

17.9

$\begin{array}{rr}5.4 & 0.4 \\ 401.6 & 97.0\end{array}$

Sealed area

$\begin{array}{lrrr}\text { Min. } & 0.9 & 5.0 & 1.4 \\ \text { Max. } & 74.1 & 319.6 & 95.4 \\ \text { Mean } & 9.5 & 32.0 & 42.2 \\ \text { Std. dev. } & 10.5 & 52.3 & 23.7\end{array}$

0.2

$\begin{array}{ll}3.3 & 2.5\end{array}$

$\begin{array}{lll}53.8 & 117.6 & 97.4\end{array}$

$13.3 \quad 28.0 \quad 54.9$

$\begin{array}{lll}11.4 & 22.7 & 26.7\end{array}$

15.2

$75.6 \quad 28.0$

Park

$\begin{array}{llll}\text { Min. } & 1.0 & 4.8 & 0.8\end{array}$

$\begin{array}{llll}\text { Max. } & 94.4 & 474.9 \quad 98.6\end{array}$

$\begin{array}{llll}\text { Mean } & 10.7 & 35.8 & 39.7\end{array}$

Std. dev. 15.1

$\begin{array}{ll}65.7 & 22.8\end{array}$

Area near the building

Min. 1.1

Max. $\quad 18.2$

$\begin{array}{ll}5.1 & 1.6\end{array}$

$130.3 \quad 94.5$

Mean $\quad 5.1$

$17.8 \quad 36.2$

Std. dev. $\quad 3.3$

$16.2 \quad 22.5$

0.2

$\begin{array}{ll}3.2 & 0.9\end{array}$

$\begin{array}{lll}98.0 & 423.4 & 99.1\end{array}$

$\begin{array}{lll}14.1 & 41.8 \quad 48.5\end{array}$

$\begin{array}{lll}14.4 & 60.6 & 28.2\end{array}$

0.3

71.5

18.9

18.2

$66.7 \quad 19.2$

Industrial area

Max. $\quad 15.9$

$\begin{array}{ll}4.6 & 19.4\end{array}$

$23.2 \quad 86.2$

Mean $\quad 6.0$

$10.6 \quad 58.8$

Std. dev. $\quad 5.0$

$\begin{array}{ll}6.9 & 22.3\end{array}$

Forest

$\begin{array}{lrrr}\text { Min. } & 0.3 & 3.7 & 1.5 \\ \text { Max. } & 34.2 & 114.8 & 93.8 \\ \text { Mean } & 4.5 & 17.3 & 36.2 \\ \text { Std. dev. } & 6.3 & 23.1 & 26.4\end{array}$

Barren land

$\begin{array}{lrrr}\text { Min. } & 0.3 & 5.1 & 0.7 \\ \text { Max. } & 34.0 & 101.8 & 93.0 \\ \text { Mean } & 4.9 & 20.6 & 33.5 \\ \text { Std. dev. } & 5.4 & 20.5 & 23.6\end{array}$

$\begin{array}{lll}0.0 & 3.6 & 0.0\end{array}$

$39.3 \quad 116.8 \quad 100.0$

$\begin{array}{lll}8.9 & 22.6 & 48.4\end{array}$

$\begin{array}{lll}7.7 & 19.7 & 27.6\end{array}$

$\begin{array}{rrr}0.2 & 9.6 & 0.2 \\ 70.4 & 441.6 & 94.9 \\ 17.6 & 72.3 & 30.1 \\ 15.6 & 66.4 & 21.1\end{array}$

$\begin{array}{lll}15.6 & 66.4 & 21.1\end{array}$

$\begin{array}{lll}0.7 & 5.8 & 0.6\end{array}$

$\begin{array}{lll}68.0 & 406.5 \quad 98.8\end{array}$

$25.4 \quad 92.1 \quad 32.0$

$\begin{array}{lll}19.6 & 72.8 & 21.4\end{array}$

$\begin{array}{lll}0.0 & 5.7 & 0.0\end{array}$

$\begin{array}{lll}21.0 & 32.2 & 92.9\end{array}$

$\begin{array}{lll}8.2 & 17.3 & 45.1\end{array}$

$\begin{array}{lll}7.1 & 9.3 & 33.6\end{array}$

0.0

$\begin{array}{rr}8.8 & 0.0\end{array}$

54.1

$422.3 \quad 96.2$

11.8

$63.6 \quad 21.7$

$\begin{array}{lll}13.3 & 58.9 & 19.0\end{array}$

$20.5 \quad 23.6$

$\begin{array}{rrr}0.4 & 4.0 & 9.1 \\ 18.2 & 81.0 & 92.7 \\ 7.3 & 17.4 & 49.7 \\ 4.4 & 15.4 & 22.2\end{array}$

$\begin{array}{rrr}0.4 & 14.8 & 0.6 \\ 21.1 & 76.0 & 29.1 \\ 6.7 & 42.8 & 17.5 \\ 7.4 & 26.6 & 10.5\end{array}$

$0.2 \quad 3.0 \quad 1.2$

$\begin{array}{lll}73.5 & 407.4 \quad 99.9\end{array}$

$43.7 \quad 46.8$

$\begin{array}{rrr}0.3 & 9.4 & 0.6 \\ 55.7 & 185.4 & 78.0 \\ 13.1 & 54.5 & 27.8 \\ 13.0 & 46.6 & 19.0\end{array}$

9.0

$\begin{array}{ll}76.2 & 31.7\end{array}$

0.4

$\begin{array}{rr}8.0 & 0.7 \\ 442.7 & 93.2 \\ 87.3 & 29.7 \\ 103.4 & 23.3\end{array}$

The second chart (Fig. 8) illustrates a newer area of the city (developed in 1970s and 1980s). Earlier, there had been large orchards, mainly cherry and plum trees with isolated parts for vineyards. Today, it is a traffic and commercial area. The distance between points $\mathrm{A}$ and $\mathrm{B}$ is about $20 \mathrm{~m}$. A humic horizon is very deep as a consequence of horticultural land use.

In Fig. 7, the misalignment of the humic horizon position is visible. This may be a remnant of mechanical cultivation. The mineral material is very different over a short distance — sands 
Fig. $6 \mathrm{Cu}, \mathrm{Pb}$ and $\mathrm{Zn}$ content in soils and their potential solubility depending on the land use form

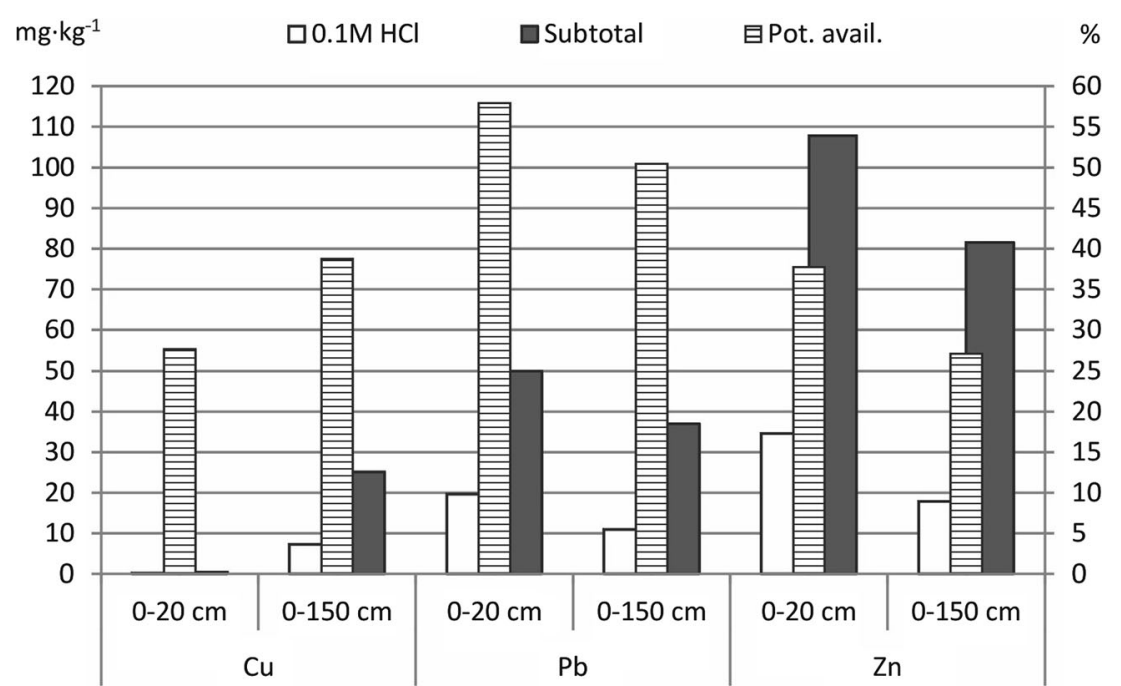

It is very difficult to precisely estimate the layout of the soil sites all over the city. Many places bear the markings of varied land use over time. Different planning concepts and possibilities of urban space creation are apparent in the transformation of the soil or lack thereof. Nowadays, the construction techniques used allow the creation of new surfaces on different soils, without the necessity of their preparatory unification. As a consequence, the soil mosaic is a kind of a historical book
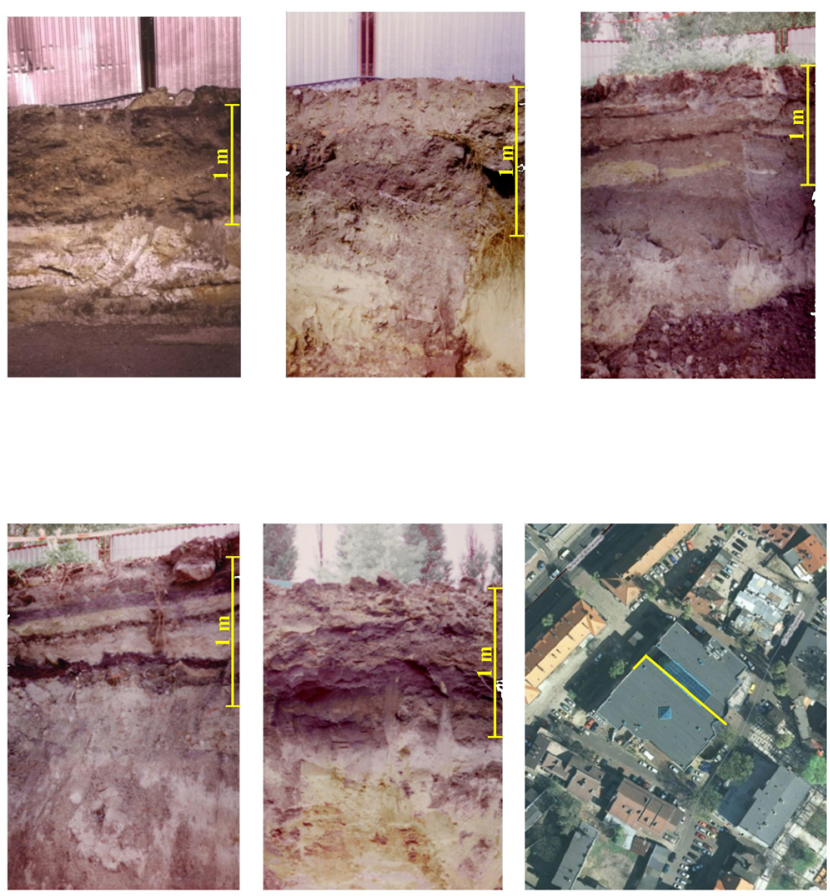

Fig. 7 Soil profiles within the commercial area in the city centre. On the left - the situation before the construction of the shopping centre; the line of excavation is marked in yellow. Soil profiles are labelled from a to e (right). In the lower right-hand corner, the area after development 


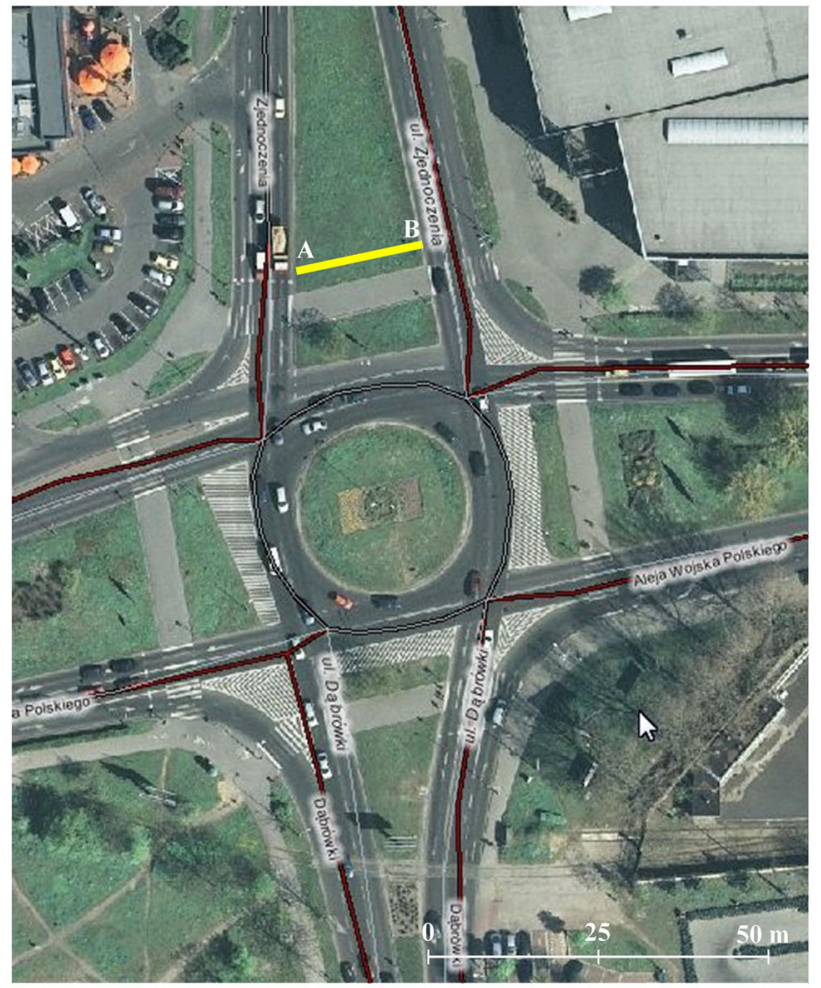

Fig. 8 Soil profiles within the traffic area near the city centre

reflecting the stages of the city's development, the technologies and techniques used and peoples' strategies in relation to their environment.

\section{Conclusions}

- The differentiation of the soil sites is significantly related to the site age, human impact intensity, including the deposition of technogenic materials and the land use form.

- The presence of technogenic materials is the factor that differentiates urban soils the most. The variability in that regard is both of qualitative and quantitative nature. Large quantities of building rubble were found in the soils of industrial areas, roadside areas, areas near buildings, but squares and barren land too.

- The transformation of the soil cover in the city of Zielona Góra is connected with an admixture of rubble and municipal wastes, which influence the skeleton content, carbonate content and $\mathrm{pH}$ of the soil. The $\mathrm{pH}$ of the soils in parks and forests is relatively lower than in the other land use forms. The content of carbonates depends on the land use form-higher results in roadsides, industrial areas, areas near buildings and sealed areas in comparison
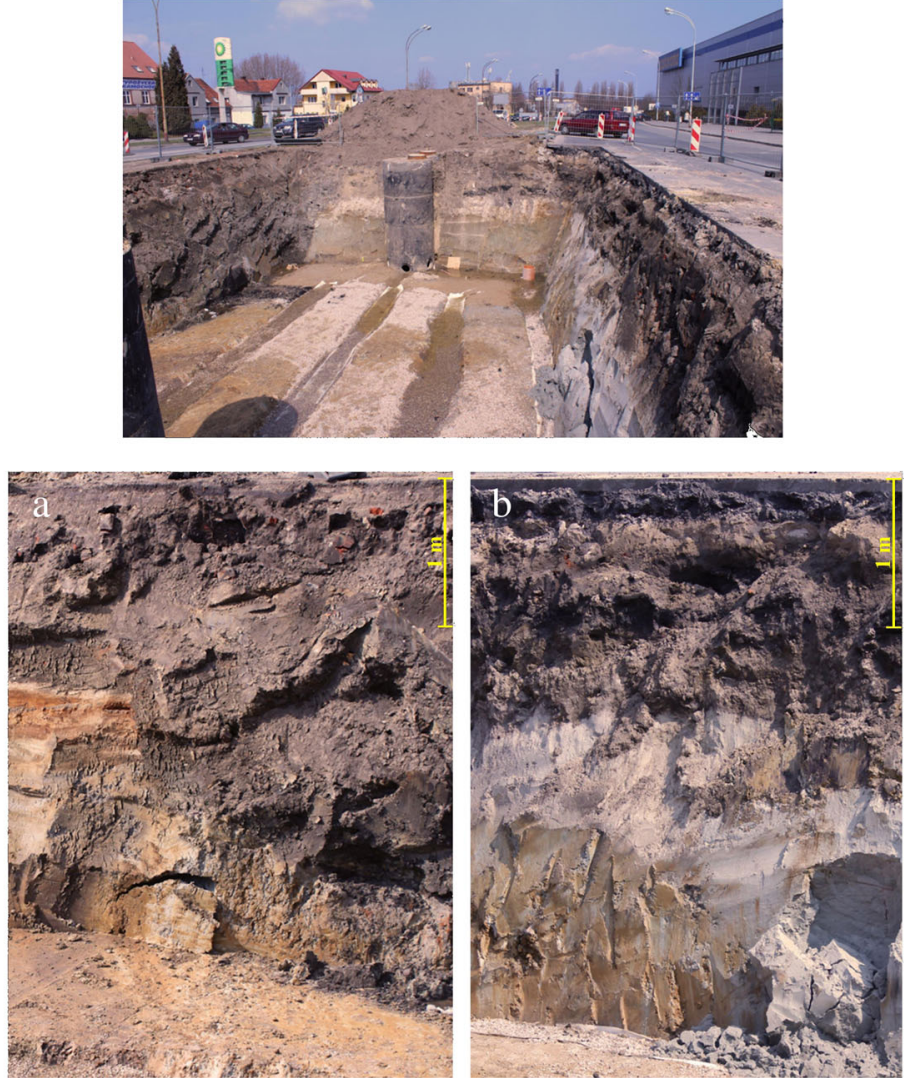

with other land use forms. In those areas, a relatively higher deposition in the topsoil than in the deeper soil horizons was found.

- The subtotal content of $\mathrm{Cu}, \mathrm{Pb}$ and $\mathrm{Zn}$ as well as the share of the heavy metal form dissolved in $0.1 \mathrm{M} \mathrm{HCl}$ in the subtotal content IS very different because of the unequal scale and intensity of human impact and different external influences. At present, the influence of reclamation activities aimed at the creation of municipal green areas is clear.

Open Access This article is distributed under the terms of the Creative Commons Attribution License which permits any use, distribution, and reproduction in any medium, provided the original author(s) and the source are credited.

\section{References}

Baker DE, Amacher MC (1982) Nickel, copper, zinc, and cadmium. In: Page AL, Miller RH, Keeney DR (eds) Methods of soil analysis. Part 2. Chemical and microbiological methods. American Society of Agronomy/Soil Science Society of America, Madison, pp 323-336 Berhane G, Welraevens K (2013) Geological and geotechnical constraints for urban planning and natural environment protection: a case study from Mekelle City, Northern Ethiopia. Environ Earth Sci 69:783798 
Blume HP, Runge M (1978) Genese und Ökologie innerstädtischer Böden aus Bauschutt. Z Pflanzenernähr Bodenkd 141:727-740

Burghardt W (1996) Urbaner Bodenschutz. Springer, Berlin-Heidelberg, p 244

Burghardt W (1995) Classification concept of substrates and soils from urban and industrial sites. In: Van Den Brink WJ, Bosmanand R, Arendt F (eds) Contaminated soil. '95, Kluwer Academic, pp 187-188

Cadenasso ML, Pickett STA (2008) Urban principles for ecological landscape. Design and management: scientific fundamentals. Cities Environ 1(Issue 2):1-16, Article 4

Charzynski P, Bednarek R, Mendyk Ł, Switoniak M, Pokojska-Burdziej A, Nowak A (2013) Ekranosols Of Torun Airfield. In: Charzyński P, Hulisz P, Bednarek R (eds) Technogenic soils of Poland. PSSS, Toruń, pp 173-190

Chernousenko G, Yamnova I, Skripnikova M (2000) Problems of anthropogenic salinization of urban soils in Moscow. In: First International Conference on Soils of Urban, Industrial, Traffic and Mining Areas, Universität-GH Essen, vol. III, pp 935-940

City Mayors (2013) Demographia world urban areas (world agglomerations), 9th annual edition, March 2013. http://www.citymayors.com/ statistics/largest-cities-density-125.html

Dancewicz A (2010) Climate and weather. In: State of the environment in Zielona Gora in 2005-2010. Biblioteka Monitoringu Środowiska, Zielona Góra, pp 13-24

EEA-European Environment Agency (2010) The European environment-state and outlook 2010-urban environment. EEA, Copenhagen, pp 42

El Khalil H, Schwartz C, Elhamiani O, Kubiniok J, Morel JL, Boularbah A (2008) Contribution of technic materials to the mobile fraction of metals in urban soils in Marrakech (Morocco). J Soils Sediments $8(1): 17-22$

Gontaszewska A, Krainski A (2007) Geology of the northern part of the Zielona Gora Moraine (near the Przylep village). Zesz. Nauk. UZ, Inż. Środ. Zielona Góra 134(14):51-60

Greinert A (2003) Studies on soils in the Zielona Góra urban area. Oficyna Wydawnicza Uniwersytetu Zielonogórskiego, Zielona Góra (in Polish), pp 168

Greinert A, Greinert H (2007) Influence of salt mine-waters overflow on the forest soils in Głogów region. Sci Rep Univ Zielona Góra Environ Eng 135(15):55-72

Greinert A, Fruzińska R, Kostecki J (2013) Urban soils in Zielona Góra. In: Hulisz P, Bednarek R, Charzyński P (eds) Technogenic soils of Poland. PSSS, Toruń, pp 31-54

Greinert A (2013) Technogenic soils in Zielona Góra. In: Charzyński P, Markiewicz M, Świtoniak M (eds) Technogenic soils atlas. PSSS, Toruń, pp 141-167

Hiller DA, Meuser H (1998) Urbane Böden. Springer Verlag, pp 161

Hulisz P, Piernik A (2013) Soils affected by soda industry in Inowrocław. In: Charzyński P, Hulisz P, Bednarek R (eds) Technogenic soils of Poland. PSSS, Toruń, pp 125-140

Huot H, Simonnot MO, Marion P, Yvon J, De Donato P, Morel JL (2013) Characteristics and potential pedogenetic processes of a Technosol developing on iron industry deposits. J Soils Sediments 13:555-568
IUSS Working Group WRB (2007) World references base for soil resources 2006. Update 2007, World Soil Resources Reports, 103, FAO, Rome

Jim CY (1998) Soil characteristics and management in an urban park in Hong Kong. Environ Manage 22(5):683-695

Kahle P, Coburger E (1996) Eigenschaften von Boden unterschiedlicher Nutzung im Stadtgebiet von Rostock. Z Pflanzenemahr Bodenk 159:637-642

Meuser H (1996) Schadstoffpotential technogener Substrate in Böden urban-industrieller Verdichtungsräume. Z Pflanzenernahr Bodenk 159:621-628

Morel J, Schwartz C, Florentin L, De Kimpe C (2005) Urban soils. In: Hillel D (ed) Encyclopedia of soils in the environment, vol 4. Elsevier, Oxford, pp 202-208

Nehls T, Rokia S, Mekiffer B, Schwartz C, Wessolek G (2013) Contribution of bricks to urban soil properties. J Soils Sediments 13:575-584

Palm V, Östlund C (1996) Lead and zinc flows from technosphere to biosphere in a city region. Sci Total Environ 192:95-109

Park S-J, Zhiqiang C, Hanbae Y, Morris EE, Sutherland M, McSpadden Gardener BB, Grewal PS (2010) Differences in soil chemical properties with distance to roads and age of development in urban areas. Urban Ecosyst 13:483-497

Pickett STA, Cadenasso ML (2009) Altered resources, disturbance, and heterogeneity: a framework for comparing urban and non-urban soils. Urban Ecosyst 12:23-44

Podgajna U (2010) Characteristics and trends of the city development. In: State of the environment in Zielona Gora in 2005-2010. Biblioteka Monitoringu Środowiska, Zielona Góra, pp 7-12

Shane DG (2005) Recombinant urbanism: conceptual modeling in architecture, urban design, and city theory. Wiley, Hoboken, p 344

Short JR, Fanning DS, Mc Intosh MS, Foss EJ, Patterson JC (1986) Soils of the mall in Washington D.C. I. Statistical summary of properties. Soil Sci Soc Am J 50:699-705

Siem HK, Cordsen E, Blume HP, Finnern H (1987) Klassifizierung von Böden anthropo-gener Lithogenese vorgestellt an Beispiel von Böden im Stadtgebiet Kiel. Mitteilgn Dtsch Bodenkundl Gesellsch 55/II:831-836

UN, Department of Economic and Social Affairs, Population Division (2011) Population distribution, urbanization, internal migration and development: an international perspective. United Nations Publication. ESA/P/WP/223

UN, Department of Economic and Social Affairs/Population Division (2012) World urbanization prospects: the 2011 revision. United Nations Publication. ESA/P/WP/224

Vassigh A, vom Hove T (2012) Urban population growth between 1950 and 2030. City Mayors statistics. http://www.citymayors.com/ statistics/urban-population-intro.html

Weber G, Olson W, Lopez SH (1984) Tour of soils of Central Park in New York City. Cornell Cooperative Extension Publication, Miscellaneous Bulletin 132, New York, p 12

Wróbel I (1989) Ground waters of the Middle Odra Land and problems of their protection. Wyd. WSInż. w Zielonej Górze, Zielona Góra 